\title{
The Removal of Sr(II) by a Nanoparticles ZnO Prepared by Microwave-Assisted Ignition Reaction
}

\author{
Ümit Hüseyin Kaynar ${ }^{*}$, Sermin Çam Kaynar² \\ ${ }^{1}$ Manisa Celal Bayar University, Education Faculty, Demirci, Manisa, Turkey \\ +90 236462 2488, u.h.kaynar@gmail.com \\ ${ }^{2}$ Manisa Celal Bayar University, Department of Physics, Yunusemre, Manisa, Turkey +90 2362013126 \\ ${ }^{*}$ Corresponding author \\ Recieved: $17^{\text {th }}$ June 2016 \\ Accepted: 27th November 2016 \\ DOI: $10.18466 /$ cbayarfbe.302767
}

\begin{abstract}
Adsorptive behavior of nanoparticles $\mathrm{ZnO}$ was assessed for removal of $\mathrm{Sr}$ (II) in aqueous media in the different trial circumstance such as the effect of parameters (time, $\mathrm{pH}$, concentration of $\mathrm{Sr}$ (II) and temperature) on sorption process. The capability of nanoparticles $\mathrm{ZnO}$ to remove $\mathrm{Sr}$ (II) from aqueous media was followed by a series of adsorption isotherms (Langmuir, Freunlinch and Temkin). The sorption percent and distribution coefficient for nanoparticles $\mathrm{ZnO}$ in ideal circumstances are $\% 96.5 \pm$ 1.76; 6959 mL.g-1 for Sr(II), respectively. According to the Langmuir adsorption model, the maximum adsorption capacity of nanoparticles $\mathrm{ZnO}$ for $\mathrm{Sr}(\mathrm{II})$ were found to be $1396 \mathrm{mg}^{-1} \mathrm{~g}^{-1}$ and sorption kinetics was preferable explained by the pseudo-second order equation. Thermodynamic data were identified. The results have been showed that nanoparticles $\mathrm{ZnO}$ was appropriate as adsorbent materiel for recovery and sorption of $\mathrm{Sr}(\mathrm{II})$ ions from aqueous media. It was found that synthesized $\mathrm{ZnO}$ powders had high capacity to recovery $\mathrm{Sr}$ (II) of the aqueous media as adsorbent.
\end{abstract}

Keywords - Microwave-assisted medhod, Nanoparticles ZnO, Sorption, Sr(II), Thermodynamic

\section{Introduction}

Many activities dealing with radioactive materials produce of radioactive wastes which require advanced treatment [1]. The removal of heavy metals and nuclear wastes in waste waters in terms of environmental protection is an important problem [2]. These heavy metals come in sight from some industrial production such as mining, nuclear and laboratory activities [3]. Strontium is an important nuclear fission product, contained in the radioactive waste of liquid effluents [4].

Sr does not cause a significant health hazards at the stable forms while $\mathrm{Sr}-90$ is not a stable isotope. The presence of Sr-90, even with low concentration in the aqueous effluents represents a serious concern. This is due to its long period of half-life (30 years) and to its great solubility in the aqueous system. Thus, Sr-90 emitting beta particles is referred to as a "bone seeker" and exposure to it will increase the risk for several diseases including bone cancer $[4,5]$.

Adsorption is a well-known, a yielding and convenient method to recover metals from waste product [6-8]. Because, it has a cheap, efficient, cheap and no chemical reagents needed for industrial and radioactive waste [9].

Nowadays the use of some natural and synthetic adsorbent such as: modified clays [9,10], montmorillonite-iron oxide composite [11], hexagonal tungsten oxide [12], $\mathrm{MnO}_{2}-\mathrm{ZrO}_{2}$ composite [13], alumina [14], activated carbons [15], bentonite [16], carbon nanotubes [17], and nanocomposite [18] 
have been tested for sorption of Sr(II) from waste waters.

Todays, one of the most significant developments in material science is nanotechnology. The word of nanomaterial is used to accentuate nanoparticles structures in the nanometer size range (1-100 nm) [19]. Nanoparticles are much more active than larger one because of their higher surface area and they show inimitable physical and chemical properties [20].

Nanomaterials have got the features of big surface area, high specificity, extreme reactivity potential for self assembly, high adsorption capacity for water treatment applications $[19,21]$. Nano metal oxides are immensely active and it is significant that both pollution control and chemical synthesis. Besides, for industrial applications, zinc oxide $(\mathrm{ZnO})$ is one of foremost used materials [22].

In surveys conducted in the last years, nanoparticles $\mathrm{ZnO}$ have been used by the sorption works $[20,23,24]$. Also $\mathrm{ZnO}$ as an adsorbent, was commonly used for adsorption of lead [25]. Additionally, as far as we know, $\mathrm{Sr}(\mathrm{II})$ sorption properties of the nanoparticles $\mathrm{ZnO}$ has not been reported so far.

It is shown in our previous study [26] that uranium (VI) adsorption percent for nanoparticles $\mathrm{ZnO}$ powders were $98.65 \% \pm 1.05$. The purpose of study was to study the high efficiency of nano- $\mathrm{ZnO}$ for remove of $\mathrm{Sr}(\mathrm{II})$. Influence of contact time, $\mathrm{pH}$, concentration of $\mathrm{Sr}$ (II) and temperature on sorption method were investigated. Balance adsorption isotherms were examined. It was calculated the values of thermodynamics of the process. The solutions of $\mathrm{Sr}$ (II) $\left(1 \mathrm{~g} . \mathrm{L}^{-1}\right)$ were made by dissolving of metal salts in milipore water. The entire chemicals used were of A.R. grade. In the said study, the crystallite structure accuracy and definition of particle size were $52 \mathrm{~nm}$ characterizations of the nano-ZnO which prepared with microwaveassisted medhod [26].

\section{Experimental}

It was necessary to optimize the experimental parameters such as contact time, $\mathrm{pH}$, initial concentrations of strontium (II) and temperature in order to obtain maximum recovery of $\mathrm{Sr}$ (II) from aqueous media. Deionized water, was used to prepare solutions and all samples. To evoluate sorption of $\mathrm{Sr}$ (II) on nanoparticles $\mathrm{ZnO}, 0.1 \mathrm{~g}$ of sorbent was equilibrated with $20 \mathrm{~mL}$ of metal solutions in 50 $\mathrm{mL}$ centrifuge tube. Adsorption of metal ions on nanoparticles $\mathrm{ZnO}$ was done using by the bacth method on the shaker (GFL 1083). For the Sr(II) concentration analysis, inductively coupled plasma-optic emission spectroscopy (ICP-OES, PerkinElmer opt. 2000) was used.

The amount of $\operatorname{Sr}(\mathrm{II})$ sorbed on nano- $\mathrm{ZnO}$ was calculated at equilibrium $\left(\mathrm{q}_{\mathrm{e}}\right)$ and at time $\left(\mathrm{q}_{\mathrm{t}}\right)$ by the formula .(2.1).

$$
q_{e, t}=\left(C_{o}-C_{e}\right) x(V / m)\left(\mathrm{mg} \cdot \mathrm{g}^{-1}\right)(2.1)
$$

$\mathrm{C}_{o}$ is the early $\mathrm{Sr}(\mathrm{II})$ concentration $\left(\mathrm{mg} . \mathrm{L}^{-1}\right), \mathrm{C}_{\mathrm{e}}$ is the amount of metal present in the media at equilibrium time $\mathrm{t}\left(\mathrm{mg} . \mathrm{L}^{-1}\right), \mathrm{m}(\mathrm{g})$ is the dry weight of sample, $\mathrm{V}(\mathrm{L})$ is the volume of metal ion concentration.

The sorption isotherms were examined via equilibrating $0.1 \mathrm{~g}$ of $\mathrm{ZnO}$ nanoparticles by varying the concentrations of metals between $25 \mathrm{mg} . \mathrm{L}^{-1}$ and $125 \mathrm{mg} \cdot \mathrm{L}^{-1}$.

The sorption activity is defined with the ions distribution coefficient, $\mathrm{K}_{\mathrm{d}}\left(\mathrm{mL} . \mathrm{g}^{-1}\right)$, determined using with formula (2.2).

$$
K_{d}=\frac{\left(C_{o}-C_{e}\right)}{C_{e}} \times \frac{V}{m}
$$

The sorption strontium (II) ions signify in a terms of sorption ratio (Ads \%) was found from by the formula (2.3).

$$
\% A d s=\frac{C_{o}-C_{e}}{C_{o}} \times 100(2.3)
$$

The influence of temperature on Strontium (II) sorption was investigated between $293 \mathrm{~K}$ and 313 $\mathrm{K}$. The thermodynamic parameters $\left(\Delta \mathrm{H}^{\circ}, \Delta \mathrm{S}^{\circ}\right.$ and $\Delta \mathrm{G}^{\circ}$ ) were calculated. This synthesis method of the sorbent and mechanism of sorption was seen in Fig.1. 


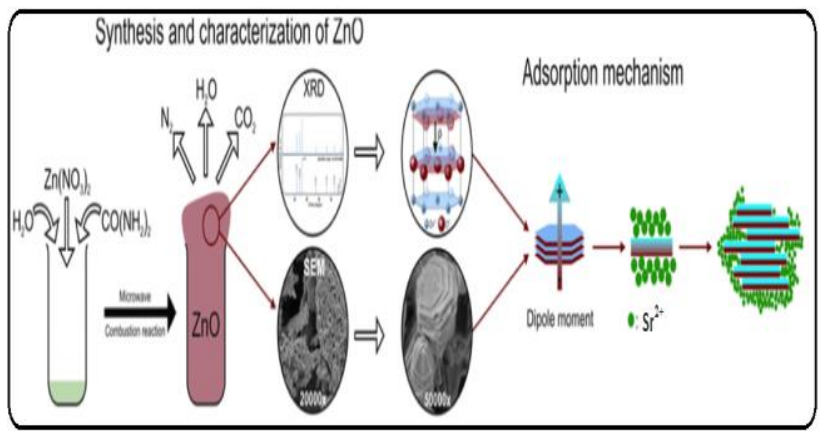

Fig. 1 The synthesis method and mechanism of the sorption.

\section{Results and Discussion}

\subsection{The Effect of Time}

Influence of contact time was investigated using a fixed concentration of strontium solutions at $293 \mathrm{~K}$. The99 time dependence of $\mathrm{Sr}(\mathrm{II})$ sorption experiments was shown in Fig.2.

The sorption of $\operatorname{Sr}(\mathrm{II})$ has been examined onto nano- $\mathrm{ZnO}$ as a function of time in the range of (15 to 120 ) min. The $\operatorname{Sr}(\mathrm{II})$ absorption efficiency is $82 \%$ at $60 \mathrm{~min}$. After that the absorption efficiencies become constant (Fig. 2).

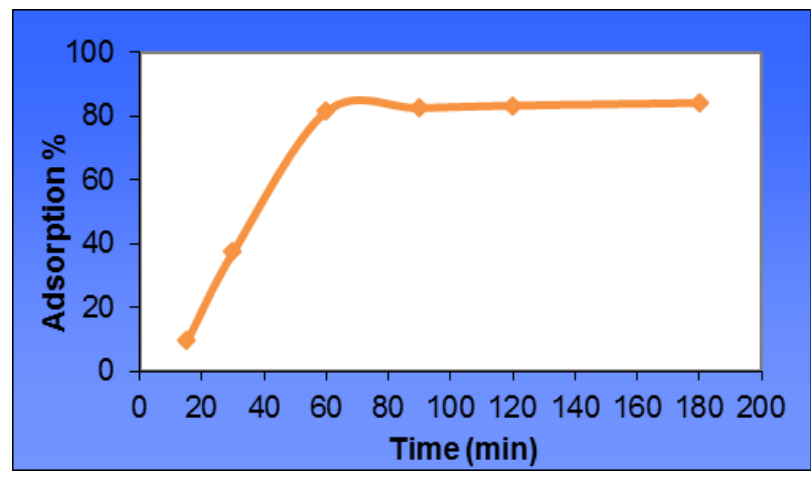

Fig. 2 Effect of contact time (m: $0.1 \mathrm{~g}$, V: $25 \mathrm{~mL}, \mathrm{pH} 3.5$, $20^{\circ} \mathrm{C}$, Const: $50 \mathrm{mg} . \mathrm{L}^{-1}$

\subsection{Effect of Solution $\mathrm{pH}$}

Influence of $\mathrm{pH}$ on the relative sorption of $\mathrm{Sr}(\mathrm{II})$ by the $\mathrm{ZnO}$ nanoparticles was shown in Fig.3.

The $\mathrm{pH}$ of sorption media has a complex phenomenonand strong influence on the ionic state of metal ions on the sorbent surfaces. The different metal ion species can occur the metallic cations in solution as a function of $\mathrm{pH}$ and metal ions [27]. The influence of $\mathrm{pH}$ on the sorption of strontium (II) on nano-ZnO was investigated (Fig.2). The sorption of
$\mathrm{Sr}(\mathrm{II})$ depending on $\mathrm{pH}$ value increased. Under the optimum adsorption conditions, $\mathrm{pH}$ was found to be 7 for $\mathrm{Sr}(\mathrm{II})$. Similar tendency for sorption of $\mathrm{Sr}(\mathrm{II})$ has been found by other researchers $[17,28]$.

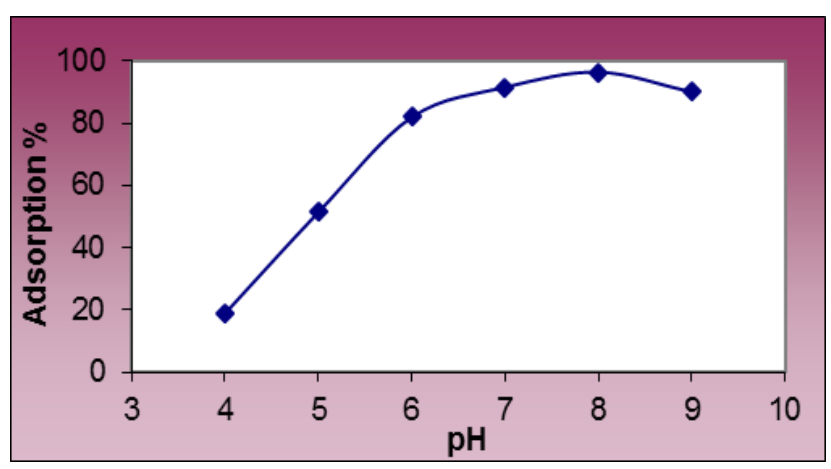

Fig. 3 Effect of solution pH. (m: 0,1 g, V:25 mL, Const: $50 \mathrm{mgL}^{-1}, 20^{\circ} \mathrm{C}$, time: $\left.4 \mathrm{~h}\right)$

\subsection{Isotherm Studies}

The aim of the sorption isotherms (Langmuir, Freundlich and Temkin) is to concern the adsorbate concentration in the media and the sorbent amount at the interface. The isotherm models are commonly used to describe the equilibrium sorption. To assess the applicability of sorption processes, the different initial metal concentrations (25-125 mg.L-1) were used.

In our work, Langmuir, Freundlich and Temkin were used to analyze the data. The Langmuir equation;

$$
\frac{C_{e}}{q_{e}}=\frac{1}{K_{L} q_{m}}+\frac{C_{e}}{q_{m}}
$$

Where $\mathrm{K}_{\mathrm{L}}\left(\mathrm{Lmg}^{-1}\right)$ is the Langmuir constant relative to the free energy of sorption, $\mathrm{q}_{\mathrm{m}}\left(\mathrm{mgg}^{-1}\right)$ is the max. monolayer adsorption capacity, plot of $\mathrm{C}_{\mathrm{e}} / \mathrm{q}_{\mathrm{e}}$ versus $C_{e}$ yields a straight line with slope $1 / q_{m}$ and intercept $1 / \mathrm{qmKL}_{\mathrm{m}}$.

Freundlich equivalence was depended on sorption on a heterogeneous surface. The equation is represented by:

$$
q_{e}=k_{f} C_{e}^{1 / n}
$$

Eq.(2.6) can be converted into another linear form:

$$
\log q_{e}=\log k_{f}+1 / n \log C_{e}
$$


Where $\mathrm{k}_{\mathrm{f}}$ is the constant of sorption capacity and $1 / n$ is the constant of sorption intensity for the Freundlich. Temkin equation stating the isotherm is given as follows:

$$
q_{e}=B \ln A_{T}+B \ln C_{e}
$$

$\mathrm{B}$ is the constant of adsorption heat $\left(\mathrm{J} \cdot \mathrm{mol}^{-1}\right)$ and $\mathrm{AT}_{\mathrm{T}}$ is equilibrium binding coefficient (L.g $\left.{ }^{-1}\right)$. Binding energy is carried out by plotting the quantity sorbed $\mathrm{q}_{\mathrm{e}}$ against $\ln \mathrm{C}_{\mathrm{e}}$ and the factors were calculated with the slope and intercept.

It is sorption isotherms of $\mathrm{Sr}$ (II) from aqueous media on to $\mathrm{ZnO}$ nanoparticles at a different temperature were shown in Fig.4.
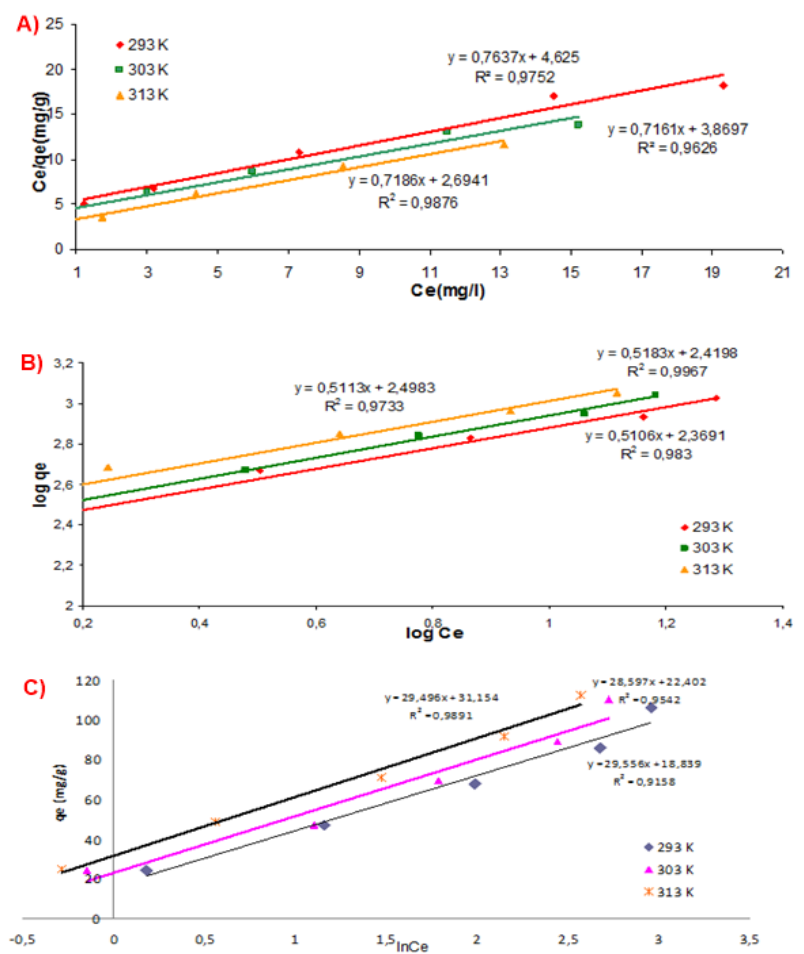

Fig. 4 Langmuir (A), Freundlich (B) and Temkin (C) plots for sorption of Sr (II) at different temperature.

It was shown Langmuir, Freundlich and Temkin constants, $\mathrm{R}$ was calculated according to Eqs.(3.1 3.4) and were given in the Table 2. Maximum adsorption capacity for Langmuir was found 1396 $\mathrm{mgg}^{-1}$. It is recommended that the $\mathrm{ZnO}$ nanoparticles under consideration can be effectively used for $\mathrm{Sr}(\mathrm{II})$ sorption from aqueous media.
Essentially, nanoprous $\mathrm{ZnO}$ exhibits very sorption performances for metal ions in comparisons with other adsorpbents given in literature and listed in Table 1 . Analyzing the data, the adsorbent used in this study is found to give better results.

Table 2 Isotherm parameters for Strontium (II) sorption onto the nano- $\mathrm{ZnO}$ at $303 \mathrm{~K}$.

\begin{tabular}{|c|c|c|}
\hline \multicolumn{3}{|c|}{ Langmuir } \\
\hline $\mathrm{q}_{\mathrm{m}}\left(\mathrm{mg} \mathrm{g}^{-1}\right)$ & $\mathrm{KL}_{\mathrm{L}}\left(\mathrm{L} \mathrm{mg}^{-1}\right)$ & $\mathrm{R}^{2}$ \\
\hline 1,396 & 0,185 & 0.9626 \\
\hline \multicolumn{3}{|c|}{ Freundlich } \\
\hline $\mathrm{K}_{\mathrm{F}\left(\mathrm{mg} \mathrm{g}^{-1}\right)}$ & $\mathrm{n}\left(\mathrm{g} \mathrm{L}^{-1}\right)$ & $\mathrm{R}^{2}$ \\
\hline 11,244 & 1,93 & 0.9967 \\
\hline \multicolumn{3}{|c|}{ Temkin } \\
\hline $\mathrm{B}\left(\mathrm{J} \mathrm{mol}^{-1}\right)$ & $\mathrm{AT}\left(\mathrm{L} \mathrm{g}^{-1}\right)$ & $\mathrm{R}^{2}$ \\
\hline 29.496 & 85.406 & 0.9891 \\
\hline
\end{tabular}

Table 1 The comparison of adsorption capacity of nanoporous $\mathrm{ZnO}$ with various adsorbent reported in the literature.

\begin{tabular}{|c|c|c|c|c|}
\hline Ions & Adsorbent & $\begin{array}{c}\text { Max.Ads. } \\
\text { Capacity } \\
\left(\mathbf{m g} \mathbf{g}^{-1}\right)\end{array}$ & $\mathbf{p H}$ & Ref. \\
\hline $\mathrm{U}(\mathrm{VI})$ & Carbonfromusedtires & 226.1 & 3.5 & {$[29]$} \\
\hline Sr(II) & Hexagonal tungsten oxide & 20.5 & 4 & {$[12]$} \\
\hline Sr(II) & $\begin{array}{c}\text { Montmorillonite- } \\
\text { ironoxidecomp }\end{array}$ & 55.5 & 6 & {$[11]$} \\
\hline $\mathrm{U}(\mathrm{VI})$ & CS/CPL composite & 536.55 & 4 & {$[30]$} \\
\hline Th(IV) & CS/CPL composite & 438.55 & 5.5 & {$[30]$} \\
\hline Th(IV) & Monazite & 1,666 & 4 & {$[31]$} \\
\hline Th(IV) & Titanatenanotubes & 232.56 & 3 & {$[32]$} \\
\hline Th(IV) & Grapheneoxide & 411 & 3 & {$[33]$} \\
\hline A.Dye & Nano-Adsorbent & 1883 & 3 & {$[34]$} \\
\hline U(VI) & Nanoporpus ZnO & 1111 & 5 & {$[26]$} \\
\hline Sr(II) & NanoporousZnO & 1,396 & 7 & $\begin{array}{c}\text { This } \\
\text { study }\end{array}$ \\
\hline & & & & \\
\hline
\end{tabular}

Freundlich isotherm parameters fits for $\mathrm{Sr}$ (II) sorption on nanoparticles $\mathrm{ZnO}$ yielded isotherms that are in a good conformity of detected conduct $\left(R^{2}\right.$ $\geq 0.99$ for Sr) (Table 2). 
Values of $\mathrm{K}_{\mathrm{f}}$ and $\mathrm{n}$ for $\mathrm{Sr}$ (II) were found to be $11.244 \mathrm{mg}^{-1} \mathrm{~g}^{-1}$ and 1.93; respectively. The Freundlich adsorption coefficient, $\mathrm{Kf}$, was raised by temperature, so the sorption process was endothermic [35].

On the Temkin plot seen in Figure 4, values of AT and $\mathrm{B}$ for $\mathrm{Sr}(\mathrm{II})$ were found to be: $85.406 \mathrm{Lg}^{-1}$, $29.496 \mathrm{Jmol}^{-1}$, respectively, It is indicative of the heat of sorption define a physical sorption process.

\subsection{Kinetics of Adsorption}

To investigate the controlling mechanism of sorption of $\mathrm{Sr}(\mathrm{II})$ ions onto the nano- $\mathrm{ZnO}$, pseudo-first and pseudo-second order kinetic equations were studied for different time intervals. The only bestfitted plot was shown in Fig. 5.

The mathematical equations were used and the plots were improved the formula:

$$
t / q_{t}=1 / K_{2} q_{e^{2}}+t / q_{e}(3.5)
$$

Where $\mathrm{qt}_{\mathrm{t}}$ and $\mathrm{q}_{\mathrm{e}}\left(\mathrm{mg}_{\mathrm{g}} \mathrm{g}^{-1}\right)$ are the amount of $\mathrm{Sr}(\mathrm{II})$ adsorbed at time $t$ and equilibrium time, respectively; $\mathrm{K}_{2}$ (mg. $\left.\mathrm{g}^{-1} \cdot \mathrm{min}\right)$ : reaction rate constant.

The related kinetic parameters have been appraised from the slopes and intercept of kinetic equations.

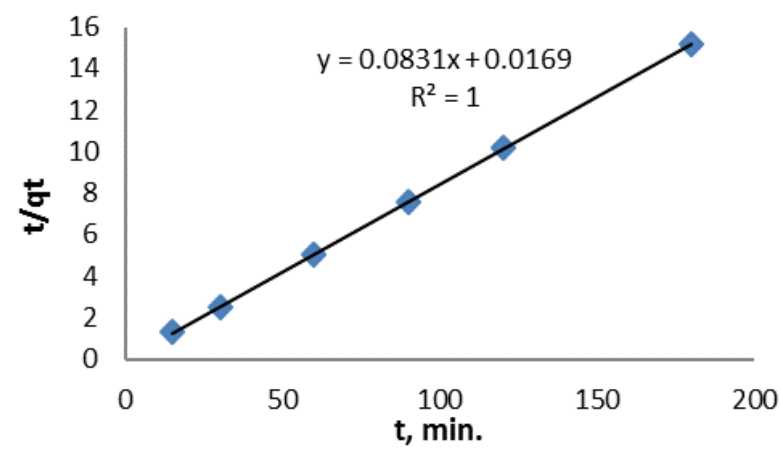

Fig. 5 The pseudo-second order adsorption kinetics of $\mathrm{Sr}$ (II) onto the nanoporous $\mathrm{ZnO}$.

The results founded from the analysis of this data have been showed that $\mathrm{Sr}$ (II) ion sorptions on $\mathrm{ZnO}$ have been defined by kinetic equation (Table 3 ).
Table 3 Kinetic parameters of Sr(II) sorption onto the by nanoporous- $\mathrm{ZnO}$

\begin{tabular}{|l|l|l|}
\hline Kinetic models & \multicolumn{2}{|c|}{ Parameters } \\
\hline Pseudo-second order & $\mathrm{R}^{2}$ & 1.0 \\
\hline $\mathrm{t} / \mathrm{q}_{\mathrm{t}}=1 / \mathrm{K}_{2} \mathrm{q}_{\mathrm{e}}^{2}+\mathrm{t} / \mathrm{q}_{\mathrm{e}}$ & $\mathrm{K}_{2}\left(\mathrm{mgg}^{-1} \mathrm{~min}^{-1}\right)$ & 0.44 \\
\hline & $\mathrm{q}_{\mathrm{e}}\left(\mathrm{mgg}^{-1}\right)$ & 12.81 \\
\hline
\end{tabular}

\subsection{Adsorption Thermodynamics}

The sorption capacity of $\mathrm{ZnO}$ nanoparticles spontaneously has increased with the temperature from 293 to $313 \mathrm{~K}$.

In thermodynamics, the enthalpy change $\left(\Delta \mathrm{H}^{\circ}\right)$ and entropy change $\left(\Delta S^{\circ}\right)$ were determined according to the Van't Hoff formula:

$$
\ln K_{d}=\left(\Delta S^{o} / R\right)-\left(\Delta H^{o} / R T\right)
$$

Where $\operatorname{lnKd}$ is the distribution coefficient $\left(\mathrm{mL}^{-1} \mathrm{~g}^{-1}\right)$, " $\mathrm{T}$ " is the temperature $(\mathrm{K})$, " $\mathrm{R}$ " is gas constant $\left(\mathrm{kJmol}^{-1} \mathrm{~K}^{-1}\right)$. The free energy values $\left(\Delta \mathrm{G}^{\circ}\right)$ were found by the formula:

$$
\Delta G^{o}=\Delta H^{o}-T \Delta S^{o}(3.7)
$$

The experiments were carried out at different temperatures $(293,303,313 \mathrm{~K})$ and constant concentration (25 mg. $\mathrm{L}^{-1}$ of $\mathrm{Sr}(\mathrm{II})$. The distribution coefficient $\left(K_{d}\right)$ values raised with temperature indicating the endothermic nature of the adsorption. $\Delta \mathrm{H}^{\circ}$ and $\Delta \mathrm{S}^{\circ}$ were obtained from the slopes and intercepts of $\operatorname{lnK}$ versus 1/T (R²: 0.96 for $\mathrm{Sr}(\mathrm{II})$ ).

\begin{tabular}{|c|c|c|c|c|c|}
\hline \multirow{2}{*}{$\begin{array}{l}\text { Metal } \\
\text { Ions }\end{array}$} & \multirow{2}{*}{$\begin{array}{c}\Delta \mathbf{H}^{\mathbf{o}} \\
\text { (kjmol- } \\
\text { 1) }\end{array}$} & \multirow{2}{*}{$\begin{array}{c}\Delta S^{o} \\
\left(\mathrm{jK}^{-1} \mathrm{~mol}^{-1}\right)\end{array}$} & \multicolumn{3}{|c|}{$\Delta \mathrm{G}^{\mathrm{o}}\left(\mathrm{kjmol}^{-1}\right)$} \\
\hline & & & $293 \mathrm{~K}$ & $303 \mathrm{~K}$ & $313 \mathrm{~K}$ \\
\hline $\mathrm{Sr}(\mathrm{II})$ & 18.4 & 139.68 & -40.91 & -42.30 & -43.70 \\
\hline
\end{tabular}

Table 4 Thermodynamic parameters for strontium sorption by nanoporous- $\mathrm{ZnO}$

The positive value of $\Delta \mathrm{H}^{\circ}$ and entropy $\left(\Delta \mathrm{S}^{\circ}\right)$ is suggestive of an endothermic nature which is favored and higher randomness of sorption in the system and favors the stability of the at higher temperature. [26]. As shown in Table 4, with increasing temperature, temperatures on nanoparticles $\mathrm{ZnO}$ occur more efficient sorption of $\mathrm{Sr}$ (II) ions at elevated. 


\section{Conclusion}

This works, the adsorption of strontium (II) ions from aqueous media with $\mathrm{ZnO}$ nanoparticles as a function of the $\mathrm{pH}$, times, metal ions and temperature were an exemined.

- The monomolecular sorption capacity of nanoparticles at optimum condition was $1,396 \mathrm{mgg}^{-1}$ for Sr (II) ions.

-According to Freundlich, values of $\mathrm{K}_{\mathrm{f}}$ and $\mathrm{n}$ for $\mathrm{Sr}(\mathrm{II})$ were obtained to be $11.244 \mathrm{mg}^{-\mathrm{g}^{-1}}$ and 1.93, respectively.

-Sorption for $\mathrm{Sr}(\mathrm{II})$ ions on $\mathrm{ZnO}$ nanoparticles is physical-chemistry sorption because $\Delta \mathrm{H}^{\circ}$ was 18.4 $\mathrm{kJ} \cdot \mathrm{mol}^{-1}$. The percent sorption (\%) and $\mathrm{Kd}_{\mathrm{d}}$ for this nanoparticles at $313 \mathrm{~K}$ were $97.9 \%$ and $8017 \mathrm{~mL}$.g1 , respectively.

- Additional, sorption of $\mathrm{Sr}$ (II) studies in the mixed $\mathrm{Cu}^{2+}, \mathrm{Pb}^{2+}$ and $\mathrm{Zn}^{2+}$ ions on nanoparticles have been investigated in acidic media. (Consantration of Sr(II): 100 ppm, Time: 60 min.; pH: 4; Mixed ions const: 25 ppm; $303 \mathrm{~K}$ ). Sorption values in the mixed metal ions for $\operatorname{Sr}(\mathrm{II})$ ions was $62 \%$. $(\mathrm{pH} 4)$.

- This Works, prepared $\mathrm{ZnO}$ nanoparticles materials are used as powerful adsorbent materials for $\mathrm{Sr}(\mathrm{II})$ ions remove for aqueous media. The data obtained from this study will not only contribute to the scientific literature, but also they will be very important in terms of the removal of the dangerous radionuclides from the environment.

\section{References}

[1] Caccin, M.; Giacobbo, F.; Ros, M.D.; Besozzi, L.; Mariani, M. Adsorption of uranium, cesium and strontium onto coconut shell activated carbon. Journal of Radioanalytical and Nuclear Chemistry. 2013; 297, 9-18.

[2] Ilaiyaraja, P.; Deb, A.K.S.; Sivasubramanian, K.; Ponraju, D.; Venkatraman, B. Removal of thorium from aqueous solution by adsorption using PAMAM dendron- functionalized styrene divinyl benzene. Journal of Radioanalytical and Nuclear Chemistry. 2013; 297, 59-69.

[3] Humelnicu, D.; Ganju, D.; Blegescu, C. Removal of uranium(VI) and thorium(IV) ions from aqueous solutions by functionalized silica: kinetic and thermodynamic studies. Journal of Radioanalytical and Nuclear Chem- istry. 2014; 299, 1183-1190.

[4] Imessaoudene, D.; Hanini, S.; Bouzidi, A. Biosorption of strontium from aqueous solutions onto spent coffee grounds. Journal of Radioanalytical and Nuclear Chemistry. 2013; 298, 893-902.

[5] Park, Y.; Shin, S.W.; Choi, S.J. Removal of cobalt and strontium from groundwater by sorption onto fishbone. Journal of Radioanalytical and Nuclear Chemistry. 2013; 295, 789-799.

[6] Agrawal, Y.K.; Shrivastav, P.; Menon, S.K. Solvent extraction, separation of uranium (VI) with crown ether. Separation and Purification Technology. 2000; 20, 177183.

[7] Liu, Y.; Liu, Y.; Cao,X.; Hua, R.; Wang, Y.; Pang, C.; Hua, M.; Li, X. Biosorption studies of uranium (VI) on cross-linked chitosan: isotherm, kinetic and thermodynamic aspects. Journal of Radioanalytical and Nuclear Chemistry. 2011; 290 (2), 231-239.

[8] Liu, R.; Fu, H.; Yin, H.; Wang, P.; Lu, L.; Tao, Y. A facile sol combustion and calcination process for the preparation of magnetic $\mathrm{Ni}_{0.5} \mathrm{Zn}_{0.5} \mathrm{Fe}_{2} \mathrm{O}_{4}$ nanopowders and their adsorption behaviors of Congo red, Powder Technology. 2015; 274, 418-425.

[9] Rahmati, A.; Ghaemi, A.; Samadfam, M. Kinetic and thermodynamic studies of uranium(VI) adsorption using Amberlite IRA-910 resin, Annals of Nuclear Energy, 2012; 39, 42-48.

[10] Zhao Y., Shao Z., Chen C., Hu J., Chen H., Zhao Y., Shao Z., Chen C., Hu J., Chen H., Effect of environmental conditions on the adsorption behavior of $\mathrm{Sr}$ (II) by Narectorite, Applied Clay Science, 2014; 87, 1-6.

[11] Ararem, A.; Bouras, O.; Bouzidi, A. Batch and continuous fixed-bed column adsorption of $\mathrm{Cs}^{+}$and $\mathrm{Sr}^{2+}$ onto montmorillonite-iron oxide composite: Comparative and competitive study. Journal of Radioanalytical and Nuclear Chemistry. 2013; 298, 537-545.

[12] Li, X.; Mu, W.; Liu, B.; Zhong, W.; Wei, H.; Jian, Y.; Zhong, Z.; Luo, S.; Li, S. Adsorption kinetic, isotherm and thermodynamic studies of $\mathrm{Sr}^{2+}$ onto hexagonal tungsten oxide. Journal of Radioanalytical and Nuclear Chemistry. 2013; 298, 47-53.

[13] Ahmadi, S.J.; Akbari, N.; Shiri-Yekta, Z.; Mashhadizadeh, M.H.; Pourmatin, A. Adsorption of strontium ions from aqueous solution using hydrous, amorphous $\mathrm{MnO} 2-\mathrm{ZrO} 2$ composite: a new inorganic ion exchanger. Journal of Radioanalytical and Nuclear Chemistry. 2014; 299 (3), 1701-1707.

[14] Guo, Z.; Yu, X.; Guo, F.; Tao, Z. Th(IV) adsorption on alumina: Effects of contact time, $\mathrm{pH}$, ionic strength and phosphate. Journal of colloid and interface science. $2005 ; 288,14-20$. 
[15] Chegrouche, S.; Mellah, A.; Barkat, M. Removal of strontium from aqueous solutions by adsorption onto activated carbon: kinetic and thermodynamic studies. Desalination. 2009; 235, 306-318.

[16] Missana, T.; García-Gutie'rrez, M. Adsorption of bivalent ions ( $\mathrm{Ca}(\mathrm{II}), \mathrm{Sr}(\mathrm{II})$ and $\mathrm{Co}(\mathrm{II}))$ onto FEBEX bentonite. Physics and Chemistry of the Earth. 2007; 32, 559567.

[17] Chen, C.; Hu, J.; Xu, D.; Tan, X.; Meng, Y.; Wang, X. Surface complexation modeling of, $\mathrm{Sr}(\mathrm{II})$ and $\mathrm{Eu}(\mathrm{III})$ adsorption onto oxidized multiwall carbon nanotubes. Journal of Colloid and Interface Science. 2008; 323, 33-41.

[18] Faghihian, H.; Iravani, M.; Moayed, M.; GhannadiMaragheh, M. A novel polyacrylonitrile-zeolite nanocomposite to clean $\mathrm{Cs}$ and $\mathrm{Sr}$ from radioactive waste. Environmental Chemistry Letters. 2013; 11, 277-282.

[19] Tian, J.; Xu, J.; Zhu, F.; Lu, T.; Su, C.; Ouyang, G. Application of nanomaterials in sample preparation. Journal of Chromatography A. 2013; 1300, 2-16.

[20] Prasad, K; Jha A.K. ZnO Nanoparticles: Synthesis and Adsorption Study. Naturel Science. 2009; 1(2), 129135.

[21] Sabikoğlu, I. Optical Characterization of $\mathrm{Eu}^{3+}$ Doped and Undoped $\mathrm{Sr}_{2} \mathrm{CeO}_{4}$ Phosphors. Manisa Celal Bayar Universty Journal of Science. 2016; 12(1), 11-15.

[22] Phuruangrat, T. and Thongtem, S. Microwaveassisted synthesis of $\mathrm{ZnO}$ nanostructure flowers. Materials Letters. 2009; 63, 1224-1226.

[23] Singh, J.; Im, J.S.; Whitten, J.E.; Soares, J.W.; Meehan, A.M.; Steeves, D.M. Adsorption of mercaptosilanes on nanocrystalline and single crystal zinc oxide surfaces. Nanophotonic Materials V. 2008; 7030, 70300T-1.

[24] Das, D.; Sureshkumar, M.K.; Koley, S., Mitha, N., Pillai, C.G.S. Sorption of uranium on magnetite nanoparticles. Journal of Radioanalytical and Nuclear Chemistry. 2010; 285, 447-454.

[25] Venkatesham, V.; Madhu, G.M.; Satyanarayana, S.V.; Preetham, H.S. Adsorption of Lead on Gel Combustion Derived Nano ZnO. Procedia Engineering. 2013; 51, 308- 313.

[26] Kaynar, Ü.H.; Ayvacıklı, M.; Kaynar, S.Ç; Hiçsönmez, Ü. Removal of uranium(VI) from aqueous solutions using nanoporous $\mathrm{ZnO}$ prepared with microwave-assisted combustion synthesis. Journal of Radioanalytical and Nuclear Chemistry. 2014; 299-3, 14691477.

[27] Sharma, P.; Sharma, M.; Tomar, R. Na-HEU zeolite synthesis for the removal of $\mathrm{Th}(\mathrm{IV})$ and $\mathrm{Eu}(\mathrm{III})$ from aqueous waste by batch process. Journal of the Taiwan Institute of Chemical Engineers. 2013; 44, 480- 488.

[28] Ahmadpour, A.; Zabihi, M.; Tahmasbi, M.; Bastami,
T.R. Effect of adsorbents and chemical treatments on the removal of strontium from aqueous solutions. Journal of hazardous materials. 2010; 182, 552-556.

[29] Mahramanlioglu, M. Adsorption of uranium on adsorbents produced from used tires. Journal of Radioanalytical and Nuclear Chemistry. 2003; 256-1, 99-105.

[30] Humelnicu, D.; Dinu, M.V.; Dragan, E.S. Adsorption characteristics of $\mathrm{UO}_{2}{ }^{2+}$ and $\mathrm{Th}^{4+}$ ions from simulated radioactive solutions onto chitosan/clinoptilolite sorbents. Journal of hazardous materials. 2011; 185, 447455 .

[31] Hussein, A.E.M. Successive uranium and thorium adsorption from Egyptian monazite by solvent impregnated foam. Journal of Radioanalytical and Nuclear Chemistry. 2011; 289, 321-329.

[32] Liu, J.; Luo, M.; Yuan, Z.; Ping, A. Synthesis, characterization, and application of titanate nanotubes for Th(IV) adsorption. Journal of Radioanalytical and Nuclear Chemistry. 2013; 298, 1427-1434.

[33] Pan, N.; Wyman, I.; Guan, D.; Jin, Y.; He, T.; Wang, R.; Xia, C. Removal of $\mathrm{Th}^{4+}$ ions from aqueous solutions by graphene oxide. Journal of Radioanalytical and $\mathrm{Nu}-$ clear Chemistry. 2013; 298, 1999-2008.

[34] Chang, Y.C. and Chen, D.H. Adsorption Kinetics and Thermodynamics of Acid Dyes on a Carboxymethylated Chitosan-Conjugated Magnetic Nano-Adsorbent. Macromolecular Bioscience. 2005; 5, 254-261.

[35] Boparai, H.K.; Joseph, M.; O'Carroll, D.M. Kinetics and thermodynamics of cadmium ion removal by adsorption onto nano zerovalent iron particles. Journal of hazardous materials. 2011; 186, 458- 465. 